\title{
SLOVKO 2013 \\ POČÍTAČOVÉ SPRACOVANIE PRIRODZENÉHO JAZYKA, KORPUSOVÁ LINGVISTIKA, E-LEARNING
}

V dňoch 13. - 15. novembra 2013 sa v Bratislave uskutočnil 7. ročník medzinárodnej bienálnej konferencie SLOVKO 2013 s podtitulom Počítačové spracovanie prirodzeného jazyka, korpusová lingvistika, e-learning, ktorú zorganizovalo oddelenie Slovenského národného korpusu Jazykovedného ústavu L'. Štúra Slovenskej akadémie vied v Bratislave (d’alej SNK JÚLŠ SAV). Konferenciu otvorili slávnostným príhovorom Zuzana Komárová, generálna riaditel'ka Sekcie umenia a štátneho jazyka Ministerstva kultúry SR, a Nicol Janočková, zástupkyňa riaditel'a Jazykovedného ústavu L'. Štúra SAV v Bratislave.

Na konferencii odznelo 27 príspevkov (z toho 3 plenárne prednášky) od viac ako 50 vedcov zo Slovenska, Česka, Mad’arska, Slovinska, Nemecka, Pol'ska a Grécka. Väčšina prezentácií bola prednesená v angličtine, niektoré odzneli v češtine a slovenčine. Po každom vystúpení bol vytvorený dostatočný priestor na diskusiu, ktorý využili účastníci konferencie na podnetné výmeny názorov a skúseností. Zborník tlačených príspevkov Natural Language Processing, Corpus Linguistics, E-learning (Eds. K. Gajdošová - A. Žáková. Lüdenscheid: RAM-Verlag 2013. 303 s. ISBN 978-3-942303-18-7), ktorý mali účastníci k dispozícii už v priebehu konferencie, obsahuje 26 príspevkov v anglickom jazyku. ${ }^{1}$ Kvalitu uverejnených príspevkov zaručuje ich posúdenie a schválenie členmi vedeckého výboru.

Príspevky sa zameriavajú na prehl'ad o súčasnom stave počítačovej lingvistiky, na možnosti zdokonal'ovania a vývoja korpusových zdrojov a nástrojov, na gramatický výskum založený na korpusových dátach a využitie korpusov a databáz na tvorbu moderných vzdelávacích portálov a vyučovanie cudzích jazykov, ako aj na interdisciplinárne témy. V správe zachytávame všetky príspevky zo zborníka, ktoré boli zároveň prezentované $\mathrm{v}$ rámci konferencie SLOVKO 2013, ako aj 2 prednášky pracovníkov SNK JÚLŠ SAV (M. Šimková, M. Debnár), ktoré odzneli v rámci programu vedeckého podujatia, pričom ich radíme podla tematických okruhov.

Plenárne prednášky predniesli odborníci na súčasnú korpusovú lingvistiku a jazykové technológie Tamás Váradi, Tomaž Erjavec a expertka na online vyučovanie Katarína Pišútová. O výsledkoch projektu CESAR (Central and South Slavic Resources) informoval jeho hlavný koordinátor Tamás Váradi (Jazykovedný ústav Mad’arskej akadémie vied v Budapešti) v štúdii Veni, Vidi, Vici: The Language Technology Infrastructure Landscape after CESAR. Tento významný projekt financovaný Európskou úniou bol zameraný na zhromaždenie základných jazykových zdrojov pre šest' slovanských jazykov strednej a juhovýchodnej Európy. V nadväznosti na širokú škálu existujúcich zdrojov a predchádzajúcich národných aj medzinárodných aktivít sa vd’aka realizácii projektu naplnila a sprevádzkovala komplexná platforma jazykových zdrojov umožňujúca a podporujúca rozsiahle multilingválne a intralingválne produkty a služby. Všetci partneri projektu vyvinuli značné úsilie o modernizáciu a skvalitnenie ponúkaných zdrojov v príslušných šiestich jazykoch. T. Váradi osobitne ocenil prácu SNK JÚLŠ SAV, ktorý poskytol korpus slovenského jazyka, ako aj mnoho d’alších kvalitne anotovaných korpusov a nástrojov, ktoré fungujú v súlade s platnou legislatívou.

${ }^{1} \mathrm{~V}$ správe uvádzame prepis mien autorov príspevkov z iných ortografických systémov do latinky tak, ako ich prepísali autori a ako sú tieto mená uvedené v zborníku z konferencie. 
Kvalifikované informácie o korpusových zdrojoch, technickej podpore a výskume v oblasti počítačovej lingvistiky v Slovinsku podal Tomaž Erjavec (Inštitút Jožefa Stefana v Lubl'ane) v príspevku Slovene Corpora for Corpus Linguistics and Language Technologies. Referenčné slovníky slovinčiny, špecializované a paralelné korpusy, ako aj korpusy cudzích jazykov sú dostupné zo serveru Inštitútu Jožefa Stefana v L'ubl'ane na adrese nl.ijs.si. Niektoré z korpusov, predovšetkým ručne anotované, sú prístupné aj na stiahnutie pod licenciou Creative Commons. Autor sa špeciálne venoval otázke dostupnosti korpusov, technickým aspektom kódovania, zachovaniu konzistentnosti a udržatel'nosti korpusov. Pozornost' tiež upriamil na právne hl'adisko a na ochranu autorských a osobných údajov. Odborné pracovisko plánuje nad'alej presadzovat' využívanie otvorených štandardov a odporúčaní, najmä usmernenia Text Encoding Initiative Guidelines, využitie open-source softvérových riešení, ako sú TreeTagger, CUWI a NoSketch Engine, a bezplatnú dostupnost' vytvorených korpusov.

Mária Šimková (Jazykovedný ústav Ludovíta Štúra Slovenskej akadémie vied v Bratislave) v prezentácii Cudzojazyčné texty v Slovenskom národnom korpuse načrtla výhody a nevýhody prítomnosti cudzojazyčných textov v Slovenskom národnom korpuse (d’alej SNK), v Slovenskom hovorenom korpuse a v d'alších korpusových zdrojoch a databázach. Poukázala na to, že v paralelných korpusoch je originál nevyhnutne prítomný, ale prítomnost' cudzojazyčných textov $\mathrm{v}$ jednojazyčnom korpuse je nežiaduca. V slovenskej publicistike, hlavne po r. 1993, sú v periodikách často prítomné celé súvislé články v češtine, ale aj v angličtine a iných jazykoch. V odbornej literatúre sú problémom inojazyčné útvary, akými sú napr. resumé, abstrakty, citáty a bibliografia. Osobitnú kategóriu predstavuje umelecká literatúra s prekladovou zložkou a výpožičkami. Autorka svoj prehl'ad uzavrela konštatovaním, že existencii cudzojazyčných textov v korpuse sa nedá vyhnút' a ich selekcia je nevyhnutná, avšak je potrebné, aby táto selekcia prebiehala $\mathrm{v}$ rozumnej miere.

Radovan Garabík a Indrè Pileckytė (Jazykovedný ústav L. Štúra Slovenskej akadémie vied v Bratislave; From Multilingual Dictionary to Lithuanian WordNet) opísali pilotnú verziu litovského WordNetu, ktorú vytvorili z dvojjazyčného slovensko-litovského slovníka. Litovský WordNet je prepojený s Princeton WordNetom a so slovenským WordNetom; v súčasnosti obsahuje 7874 substantívnych, 2099 adjektívnych a 682 adverbiálnych synsetov (množiny slov s rovnakým významom), ktorým prislúchajú slovenské a anglické ekvivalenty, pričom všetky synsety prešli manuálnou opravou. V najbližšom čase plánujú tvorcovia litovského WordNetu skorigovat' slovesné synsety, ktorých je zatial' 533, a kvantitatívne rozšírit' existujúcu databázu.

Vývoj korpusových nástrojov, ktoré zohrávajú významnú úlohu pri skvalitňovaní korpusov a zefektívňujú lexikografickú prácu, ako aj aplikácia jazykových technológií v praxi boli predmetom záujmu autorov aj autorských kolektívov z viacerých inštitúcií.

Nové vylepšené vyhl'adávacie rozhranie NoSketch Engine (d’alej NoSkE) vhodné pre rôzne druhy korpusov predstavili jeho tvorcovia Tomáš Ma chálek a Michal Křen (Filozofická fakulta Karlovej univerzity v Prahe; Query Interface for Diverse Corpus Types). Medzi nové najdôležitejšie funkcie softvéru NoSkE patria hierarchické usporiadanie dostupných korpusov vrátane zobrazenia charakteristiky každého z nich, ponuka interaktívneho výberu morfologických kategórií pre CQL, podpora pre hovorené korpusy (možnost' prehrávat' zvukové segmenty). Softvér NoSkE má v Českom národnom korpuse (d'alej ČNK) po d’alších vylepšeniach funkčnost'ou prekonat' a nahradit' vyhl'adávacie rozhrania Park a Bonito. Na tomto mieste 
treba pripomenút', že nový vyhl'adávací systém vd'aka spolupráci s ČNK môžu využívat' na vyhl'adávanie aj používatelia SNK. Oddelenie SNK JÚLŠS SAV sa prostredníctvom testovania, návrhov a pripomienok spolupodiel'a na zdokonal'ovaní nového rozhrania NoSkE.

Vyhl'adávaním a odstraňovaním duplikácií v dátach SNK sa zaoberal Vladimír Benko (Jazykovedný ústav L. Štúra Slovenskej akadémie vied v Bratislave; Data Deduplication in Slovak Corpora). Detekcia presných duplikácií je podl’a autora jednoduchá, náročnejšie je vyhl’adávanie blízkych duplikácií a určenie primeranej miery ich eliminácie. Na detekovanie blízkych duplikácií použil kombináciu dvoch nástrojov: jednoduchú metódu fingerprint a nástroj Onion („One Instance Only”), ktorý vytvoril Jan Pomikálek z Masarykovej univerzity v Brne. V. Benko plánuje v budúcnosti skvalitnit' použité metódy a aplikovat' svoj výskum na všetky podkorpusy Slovenského národného korpusu, ako aj na novovytvorený webový korpus SNK.

Kamil Barbierik, Martina Holcová Habrová, Pavla Kochová, Tomáš Liška, Zdeňka Opavská a Miroslav Virius (Ústav pro jazyk český Akadémie vied Českej republiky v Prahe) predstavili vo svojom príspevku A New Path to a Modern Monolingual Dictionary of Contemporary Czech: the Structure of Data in the New Dictionary Writing System nový špeciálny software Dictionary Writing System, ktorý sa využíva pri tvorbe výkladového slovníka súčasnej češtiny. Heslár slovníka je vygenerovaný na základe 3 vyvážených korpusov SYN2000, SYN2005, SYN2010. Vývoj softvéru a lexikografickú prácu podporuje grant z Ministerstva kultúry ČR v rámci programu aplikovaného výskumu a vývoja Národnej a kultúrnej identity.

Michal Laclavík, Štefan Dlugolinský (Ústav informatiky Slovenskej akadémie vied v Bratislave) a Michal Blanárik (Fakulta informatiky a informačných technológií Slovenskej technickej univerzity v Bratislave) diskutovali v článku Experimenting with Slovak Wikipedia as a Source for Language Technologies o možnostiach využitia slovenskej Wikipédie na spracovanie prirodzeného jazyka. Na jej dátach overili niektoré metódy a algoritmy na rozpoznávanie názvoslovných entít. Ich ciel’om bolo poukázat' na to, že slovenská Wikipédia má široké využitie v štatistickom spracovaní prirodzeného jazyka a môže slúžit’ ako relevantný a dostupný zdroj textových dát.

V príspevku Event Extractor: Email Events Detection and Calendar Integration prezentovali Filip Ogurčák (Fakulta informatiky a informačných technológií Slovenskej technickej univerzity v Bratislave) a Michal Laclavík (Ústav informatiky Slovenskej akadémie vied v Bratislave) svoj prístup k automatickému detekovaniu udalostí (dátum, čas, miesto, názov) z malého korpusu slovenských emailových správ a ich následné editovanie a uloženie do kalendára pomocou extrakčnej metódy. Opísali plugin pre Thunderbird, ktorý predstavuje klientsku čast' aplikácie a grafické rozhranie na pridávanie udalostí do Google kalendára, ako aj serverovú čast' aplikácie, ktorá zabezpečuje prepojenie detekovanej udalosti s pluginom pre Thunderbird a jednotlivými extrakčnými metódami.

Korpusové nástroje, programy a aplikácie, ktoré sú témou aj nasledujúcich príspevkov, vznikajú a zdokonal'ujú sa s ciel'om efektívneho vyhl'adávania viacslovných pomenovaní, frazém a iných l'ubovol’ne zvolených slov a syntagiem, poskytujú tiež mnoho d’alších podnetov na lingvistické analýzy a zlepšujú možnosti práce s korpusmi. Vd’aka tomu ich môžu efektívne využívat' novinári, prekladatelia, pedagógovia a široká verejnost'.

Ján Staš, Daniel Hládek, Jozef Juhár (Katedra elektroniky a multimediálnych telekomunikácií Technickej univerzity v Košiciach) a Martin Ološtiak (Filozofická fakulta 
Prešovskej univerzity v Prešove) v príspevku Automatic Extraction of Multiword Units from Slovak Text Corpora predstavili vlastný spôsob automatickej extrakcie viacslovných pomenovaní z rozsiahlych textových korpusov. Pomocou dostupných textov na internete vytvorili 4 podkorpusy zamerané na špecifické oblasti (novinové články, súdne texty, beletristické texty a web) a pre každú z nich navrhli morfologicky motivovaný a štatistický prístup na extrakciu relevantných viacslovných pomenovaní, ktorá môže byt' užitočná pri klasifikácii a kategorizácii textových dokumentov, pri automatickej korekcii textu a porovnávacom lingvistickom výskume.

Ralitsa Dutsova a Ludmila Dimitrova (Inštitút matematiky a informatiky Bulharskej akadémie vied v Sofii) v príspevku Software System for Processing Bulgarian Digital Resources: Parallel Corpora and Bilingual Dictionaries informujú o systéme spracovania a webovej prezentácii bulharských digitálnych zdrojov. Modul Search je softvérový nástroj na extrakciu dát z bilingválnych slovníkov, ktorý má implementované rozličné parametre vyhl'adávania z oblasti morfosyntaxe, derivatológie a metriky. Táto webová aplikácia je v súčasnosti experimentálnym nástrojom s flexibilnou štruktúrou a možnost'ou rozšírenia o d'alšie funkcie. Podl’a autoriek ide o užitočný nástroj so širokými možnost’ami uplatnenia vo výskume, pri tvorbe lexikálnych databáz, v translatológii a pri výučbe jazykov.

Rozpoznávaním združených pomenovaní v gréčtine sa zaoberali Vasiliki Foufi, Kyriaki Ioannidou a Olympia Tsaknaki (Filozofická fakulta Aristotelovej univerzity v Solúne; Obstacles and Solution to Recognizing Compound Nouns in Greek: A Corpus Study). Sústredili sa na vyhl'adávanie syntagiem zložených $\mathrm{z}$ adjektív a substantív, ktoré sa v gréčtine často vyskytujú ako nekompaktné štruktúry prerušené v texte inými vloženými slovami. Na vyhl'adávanie použili špeciálnu FST metódu (konečný stavový transducer, t. j. automat s 2 páskami), ktorú aplikovali na dáta korpusu gréckych publicistických textov s rozsahom približne 6 miliónov textových jednotiek. Výsledky hl'adania pomocou FST metódy sú uspokojivé, nástroj sa však môže d'alej zdokonal'ovat' tak, aby sa pomocou neho dali vyhl'adávat' aj d'alšie typy združených pomenovaní.

V príspevku Identification of Idioms in Spoken Corpora predstavili Milena Hnátková a Marie Kopřivová (Filozofická fakulta Karlovej univerzity v Prahe) program FRANTA, ktorý bol vyvinutý na automatickú identifikáciu frazém v hovorených korpusoch ČNK (Pražský mluvený korpus, d’alej PMK, ORAL2006, ORAL2008). Doteraz sa frazémy v PMK vyhl'adávali a identifikovali manuálne, preto sa teraz môže porovnávat' efektivita automatickej a manuálnej identifikácie frazém. Autorky opísali výhody a nevýhody oboch postupov a načrtli d'alšie možnosti, ako spresnit' vyhl'adávanie idiómov v prepisoch hovorených prejavov.

Kateřina Veselovská (Matematicko-fyzikálna fakulta Karlovej univerzity v Prahe) predstavila v príspevku Czech Subjectivity Lexicon: A Lexical Resource for Czech Polarity Classification český lexikón subjektivity určený na analýzu nálady v českých textoch. Lexikón tvorí 4947 hodnotiacich položiek zatriedených podl'a slovných druhov s označenou pozitívnou alebo negatívnou polaritou. Jadro českého lexikónu subjektivity vzniklo automatickým prekladom vol’ne dostupného anglického slovníka subjektivity, ktorý sa následne využil na testovanie na dátach získaných z českých spravodajských a d’alších internetových portálov. Slovník je potrebné d’alej vylepšovat', už jeho prvá verzia však poskytuje účelný lexikálny zdroj na sémantické analýzy a výskum hodnotenia v jazyku. 
Uliana Yazhinova (Oddelenie slovanských štúdií Humboldtovej univerzity v Berlíne, Oddelenie slovanských štúdií Univerzity v Regensburgu; A Corpus-based Analysis of the Functionality and the Meaning of Infinitive „Frustrative Construction” in Czech and Slovak) skúmala infinitívne „konštrukcie frustrácie” v slovenčine a v češtine. Konštrukcie n(i)e a n(i)e + infinitív predstavujú jedinečné sémantické štruktúry, ktoré vyjadrujú subjektívnu, často negatívnu reakciu zo strany aktora alebo zúčastneného pozorovatel'a na neočakávaný alebo nežiaduci výsledok akcie. Autorka na základe analýzy dát z korpusov ČNK, SNK a doplnkových dát $\mathrm{z}$ internetu podrobne opísala funkčné vlastnosti tejto kompaktnej konštrukcie a porovnala výsledky pre češtinu a slovenčinu.

Daša Munková (Pedagogická fakulta Univerzity Konštantína Filozofa v Nitre), Michal Munk a Martin Vozár (Fakulta prírodných vied Univerzity Konštantína Filozofa v Nitre) sa $\mathrm{v}$ príspevku The Effect of Stop Words Elimination on Sequence Patterns Extraction in Comparable Corpora zamerali na stop slová (hlavne predložky a spojky), ktoré skúmali na dátach dvoch porovnatel'ných korpusov reklamných textov, pričom každý z nich obsahoval 600 reklamných textov. Výsledky analýzy ukázali, že iba jazyk má signifikantný vplyv na množstvo a kvalitu extrahovaných pravidiel v porovnatel'ných korpusoch anglických a slovenských textov a odstraňovanie stop slov na základe vopred vytvoreného zoznamu je pri analýze takýchto krátkych textov neefektívne.

Korpusová lingvistika má svoje miesto v modernej filológii aj interdisciplinárnom výskume. Rozličné korpusy poskytujú vel'ké množstvo dostupných, prehl'adných a utriedených dát, vd'aka čomu sa mnohé hypotézy a teórie spol'ahlivejšie a efektívnejšie overujú a samotný lingvistický výskum sa tak zdokonal’uje. Vlastný výskum vybraných javov z morfológie, syntaxe, valencie a sémantiky zachytilo vo svojich štúdiách viacero nižšie uvedených autorov z Česka a zo Slovenska.

K najfrekventovanejším slovným tvarom $\mathrm{v}$ češtine patria reflexíva $s a$ a si. Na báze korpusu súčasnej češtiny SYN2010 s rozsahom 100 miliónov slovných jednotiek ich detailne skúmal Vladimír Petkevič (Filozofická fakulta Karlovej univerzity v Prahe; Formal (Morpho)Syntax Properties of Reflexive Particles se, si as Free Morphemes in Contemporary Czech). V štúdii sa zaoberá predovšetkým vzt’ahom reflexív k ich nadradeným slovám, ktorými môžu byt' slovesá, deverbatívne adjektíva alebo deverbatívne substantíva. Špecifikácia vlastností reflexív môže prispiet' k zlepšeniu automatickej morfologickej dezambiguácie korpusových dát, ako aj k spresneniu syntaktickej analýzy textov súčasnej češtiny.

Jedným z najnáročnejších problémov pri anotácii ručne značkovaného korpusu slovenčiny r-mak (verzie 1.0 - 4.0) bola delimitácia particípií. Podrobnému opisu anotácie particípií a riešeniu hraničných prípadov sa venovala Agáta Karčová (Jazykovedný ústav L. Štúra Slovenskej akadémie vied v Bratislave) v príspevku Delimitation of Participles in the Manual Morphological Annotation. Autorka objasňuje, prečo sa particípiá v SNK vyčleňujú ako samostatná slovná trieda, venuje sa prípadom homonymie, analogicky vytvoreným tvarom a určovaniu lexém, ktoré stoja na rozhraní tried particípiá - adjektíva a particípiá - substantíva. Obhajuje formálny prístup pri anotácii particípií, ktorý sa ukázal ako logický a spol’ahlivý.

Veronika Kolářová (Matematicko-fyzikálna fakulta Karlovej univerzity v Prahe) vo svojom príspevku Agents Expressed by Prepositionless Instrumental Modifying Czech Nouns Derived from Intransitive Verbs opísala české deverbatívne substantíva, ktoré umožňujú zmenu agensa vyjadreného bezpredložkovým inštrumentálom. Schopnost' substantíva byt' rozvi- 
tým konatel’om v bezpredložkovom inštrumentáli sa tradične považuje za jedno z kritérií pri stanovovaní dejového významu substantíva. Hlavnou otázkou, na ktorú sa autorka zamerala, bolo, či je konatel' v bezpredložkovom inštrumentáli gramaticky správny aj pri substantívach odvodených z netranzitívnych slovies.

Václava Kettnerová, Markéta Lopatková, Eduard Bejček, Anna Vernerová (Matematicko-fyzikálna fakulta Karlovej univerzity v Prahe) a Marie Podobová (Slovanský ústav Akadémie vied Českej republiky v Prahe) v príspevku Corpus Based Identification of Czech Light Verbs zhrnuli možnosti identifikácie českých kategoriálnych slovies. Na odlíšenie použitia slovies v ich kategoriálnom význame od ich plnovýznamového použitia aplikovali test redukcie, koreferenčný test a doplnkové kritérium na anotáciu pomocných slovies. Prijaté kritériá overovali paralelnou anotáciou vel'kého množstva dát získaných z ČNK. Výsledkom anotácie sú tzv. „zlaté dáta“, ktoré pozostávajú z 893 kombinácií kategoriálnych slovies a predikatívnych podstatných mien, ktoré sa využijú pri tvorbe valenčného slovníka českých slovies VALLEX.

Autorky príspevku Verb Valency and Argument Non-correspondence in a Bilingual Treebank Jana Šindlerová, Zdeňka Urešová a Eva Fučíková (Matematicko-fyzikálna fakulta Karlovej univerzity v Prahe) prezentovali na materiáli česko-anglického závislostného korpusu rozličné realizácie valenčných rámcov slovies v rámci rovnakej sémantickej triedy, zamerali sa na slovesá vyjadrujúce súd (v širokom zmysle slova, napr. obvinit', prisúdit', usvedčit', vytknút' a iné). S ohl'adom na túto triedu slovies analyzovali príklady a zvažovali prirodzenost' „tretieho argumentu“ vo valenčnej štruktúre. Navrhli konkrétny spôsob unifikovania anotačnej praxe pre danú triedu slovies a možné spôsoby na upravenie valenčnej teórie pre potreby viacjazyčných dát.

Kateřina Najbrtová (Filozofická fakulta Masarykovej univerzity v Brne) v príspevku Valency of Selected Primary Adjectives in the SYN2010 Corpus opísala valenčné rámce primárnych adjektív analyzovaných na textoch korpusu SYN2010. Autorka vychádzala zo starších štúdií $\mathrm{H}$. Prouzovej a M. Kopřivovej, porovnala ich valenčné rámce adjektív a vybrala $\mathrm{z}$ nich konkrétne adjektíva, ktoré testovala na materiáli korpusu SYN2010. Vytvorila rozsiahly zoznam primárnych adjektív s valenciou a frekvenčnou štatistikou a podrobne opísala valenciu najčastejších z nich. Zistila tiež, že ak existuje možnost' valenčných doplnení primárnych adjektív infinitívom, potom je toto doplnenie vždy početnejšie ako doplnenie vedl'ajšou vetou.

Zdeňka Hladká (Filozofická fakulta Masarykovej univerzity v Brne) príspevkom Corpora of Private Correspondence as a Source of Material Focused on a Research of Diminutives upriamuje pozornost' na dôležitý zdroj lingvistických dát - korpus súkromnej korešpodencie. Zo špecializovaného korpusu KSKdopisy, ktorý vznikol na Masarykovej univerzite a obsahuje 2000 súkromných listov, Z. Hladká vytvorila podkorpus mladých autorov (mladších ako 30 rokov) obsahujúci 300 listov, ktorý slúžil na skúmanie deminutív. Súčast'ou príspevku je zoznam vyexcerpovaných deminutív, údaje o ich frekvencii a základné informácie týkajúce sa ich lexikografickej reflexie.

Nasledujúce príspevky sa venujú využívaniu korpusov vo vyučovaní, vytváraniu špeciálnych korpusov a cvičení na didaktické ciele a tiež prehl'adu o online vzdelávaní a jeho špecifikách v porovnaní s klasickým spôsobom vyučovania.

Jedným z ciel'ov príspevku Kataríny Pišútovej (Centrum informačných technológií Univerzity Komenského v Bratislave; Introduction to Online Learning) bolo poskytnút' klú- 
čové informácie o online vzdelávaní. Autorka sa venovala základným historickým faktom o vzniku online vzdelávania, na základe ktorých sa pokúsila o výstižnú definíciu tohto moderného spôsobu vzdelávania. Vymedzila aj rozdiely medzi tradičným a online vyučovaním. Druhá čast' príspevku bola venovaná rozvoju online vzdelávania na Slovensku a problémom, ktoré sú špecifické pre našu situáciu (technické problémy, novost' tejto formy vzdelávania, nedostatky v štruktúre kurzov a i.).

Grzegorz Krynicki (Fakulta angličtiny Univerzity Adama Mickiewicza v Poznani) prezentoval vo svojom príspevku Corpus-based Online Word Formation Exercises for Advanced Learners of English - Challenges and Solutions návrh a prevádzku online platformy určenej na vyučovanie angličtiny ako cudzieho jazyka. Vytvoril cvičenia zamerané na tvorbu slov, doplnené o ukážkové vety, ktoré sa jednoduchou metódou automaticky extrahujú z Britského národného korpusu. Takéto cvičenia obohatené o autentický vetný kontext rozvíjajú schopnosti žiaka učit' sa gramatiku a ul'ahčujú pochopenie významov, vzt’ahov a kolokácií slov cudzieho jazyka.

Špecializovaný korpus môže slúžit’ ako cenný zdroj údajov, z ktorých sa dajú zistit’ časté chyby vyskytujúce sa v procese osvojovania si cudzieho jazyka. K tomuto záveru dospela na základe výskumu Andrea Hudousková (Filozofická fakulta Karlovej univerzity v Prahe; The Corpus CzeSL in the Service of Teaching Czech for Foreigners - Errors in the Use of the Pronoun který). Autorka pracovala s dátami nereferenčného korpusu CzeSL, ktorý bol sprístupnený v roku 2012 a je zostavený z písomných prác študentov učiacich sa češtinu ako cudzí jazyk s rozsahom približne 2 mil. slov. Autorka sa zamerala na vyhl'adávanie chýb pri používaní vzt’ažného zámena který a konfrontovala rozsah zistených chýb s opismi vzt’ažnej vety $\mathrm{v}$ učebniciach a gramatikách češtiny.

Špecifický prienik sémantiky, antropológie, filozofie a korpusovej lingvistiky badat' vo výskume T. Timoshchenkovej a M. Debnára.

Tatiana Timoshchenko (Filozofická fakulta Karlovej univerzity v Prahe) vo svojom príspevku Determination of Czech BCT Prototypes on the Basis of Corpus Data sémanticky analyzovala prototypy základnej farebnej terminológie v češtine (Basic Color Terms, skr. BCT) skúmanej na korpusových dátach. Stanovenie jadra farebných kategórií spočívalo v hl’adaní charakteristických prírodných entít ako kognitívnych referenčných bodov. V štúdii vyčleňuje 3 typy lingvistických konštrukcií: prirovnávacie (černý jako uhel), príslovkové (křídově bílý) a inštrumentálne (šedý prachem). V prirovnaniach sa BCT prototypy odhal'ujú rovnomerne, adverbiálna konštrukčná analýza je efektívnejšia na opis sémantického pol’a BCT a inštrumentálna konštrukcia sa podl'a autorky osvedčila ako zdroj koncepčnej metonymie.

Marek Debnár (Jazykovedný ústav L. Štúra Slovenskej akadémie vied v Bratislave) predstavil vo svojej prezentácii Možnosti spracovania sémantických poli v Slovenskom národnom korpuse niektoré prieniky filozofie a jazyka. Načrtol možnosti využitia korpusov pre širšie humanitné bádanie, najmä literárno-teoretické, semiotické a filozofické. Takisto navrhol zaviest' do štýlovo-žánrovej anotácie textov v Slovenskom národnom korpuse kl’úč „narrator“, ktorý by zaznamenával perspektívu rozprávača $\mathrm{v}$ umeleckých textoch, čo by umožnilo štatistické skúmanie textov rôznych umeleckých období a oblastí z hl'adiska subjektivizácie výpovede.

V závere medzinárodnej konferencie SLOVKO 2013 sa Mária Šimková, vedúca oddelenia SNK JÚLŠS SAV, pod'akovala všetkým zúčastneným aj prednášajúcim za aktívnu účast' na 
konferencii, príjemnú a priatel'skú atmosféru počas celého podujatia, recenzentom zborníka za ich kvalitnú prácu a zaželala všetkým pozitívne prínosy z rokovaní pre d’alšie projekty v oblasti počítačového spracovania prirodzeného jazyka. Zároveň vyjadrila želanie, aby sa v duchu profesionality a spolupráce odohrala aj plánovaná konferencia SLOVKO 2015.

Agáta Karčová - Beáta Kmetová

Jazykovedný ústav L. Štúra SAV, Bratislava 